\title{
Assessment of Gene Expression Level of ATP Binding Cassette G Member 2 (ABCG2) Transporter in Newly Diagnosed Breast Cancer Patients Receiving Adjuvant Chemotherapy
}

\author{
Shaimaa A. Soliman ${ }^{1}$, Laila A. Rashed ${ }^{2}$, Mahmoud M. Said ${ }^{3, *}$ and Amina M. Medhat ${ }^{3}$ \\ ${ }^{1}$ El-Salam Oncology Specialized Center, Ministry of Health, Cairo, Egypt \\ ${ }^{2}$ Department of Medical Biochemistry, Faculty of Medicine, Cairo University, Egypt \\ ${ }^{3}$ Biochemistry Department, Faculty of Science, Ain Shams University, Cairo, Egypt
}

\begin{abstract}
The efficacy of cancer chemotherapy is limited by cellular mechanisms of resistance that result in increased drug efflux of chemotherapeutic agents thereby reducing intracellular drug levels and causing drug resistance. Overexpression of some members of ATP binding cassette transporter superfamily, including ATP binding cassette G member 2 (ABCG2), which mediates energy-dependent transport of drugs out of the cells against concentration gradient, is one of the major mechanisms responsible for multidrug resistance in the treatment of breast cancer. In the current study, the expression of ABCG2 mRNA gene was evaluated in the peripheral blood of newly diagnosed breast cancer (NDBC) patients immediately before surgical resection of the breast and in extirpated breast tumors, then sequentially in the blood of patients after receiving three and six cycles of chemotherapy. Compared to normal breast, cancerous specimens expressed higher levels of ABCG2 gene expression $(p<0.001)$. In addition, a gradual significant increase in the expression of peripheral blood ABCG2 gene of NDBC patients among different treatment periods was recorded. Furthermore, a significant positive correlation between peripheral blood ABCG2 gene expression of NDBC patients receiving chemotherapy and disease progression was found. In conclusion, assessment of ABCG2 gene expression may be a prerequisite in evaluating the effectiveness of chemotherapy-treated breast cancer patients.
\end{abstract}

Keywords: ABCG2, adjuvant chemotherapy, breast cancer, mastectomy, multidrug resistance, progression.

\section{INTRODUCTION}

Breast cancer is the most common malignancy and the leading cause of cancer-related deaths among women worldwide [1]. In Egypt, the incidence of breast cancer ranks second after liver cancer, with 23,081 newly diagnosed cases in 2018 , representing $35.1 \%$ of all female cancers $(23,081 / 65,693)$, and 9,254 deaths that represent $23.8 \%$ of all female cancer deaths $(9,254 / 38,814)[2]$.

The acquisition of resistance to multiple structurally unrelated compounds, known as multidrug resistance (MDR), is considered a frequent problem in the treatment of cancer and most patients with metastatic cancer die from multidrug resistant disease [3]. Furthermore, resistance to chemotherapeutic drugs by cancer cells may also be acquired over the course of therapy [4].

ATP-binding cassette (ABC) transporters are dedicated transport proteins that mediate translocation of diverse physiological and xenobiotic substrates across cellular membranes in an ATP-dependent manner. Seven human ABC protein subfamilies, $A$ to $G$, are known. ATP binding cassette $G$ member 2

*Address correspondence to this author at the Department of Biochemistry, Faculty of Science, Ain Shams University, Cairo, Egypt; Tel: +201148871573; E-mail: mahmoudmsaid@sci.asu.edu.eg
(ABCG2, also known as breast cancer resistance protein $\mathrm{BCRP}$ ), is a half transporter that plays an essential role in physiological detoxification across tissue barriers, including the placental, mammary epithelium or blood brain barrier. In addition, ABCG2 and the related $A B C$ transporters $P$-glycoprotein (ABCB1) and multidrug resistant protein-1 (MRP1 or $A B C C 1$ ) act as brothers in arms in multidrug resistance phenomena in cancer [5]. ABCG2 is the principal $A B C$ transporter involved in the multidrug resistance of breast cancer [6]. Overexpression of ABCG2 can render the cancer cells resistant to the ABCG2 substrate chemotherapy agents, including mitoxantrone, doxorubicin and several tyrosine kinase inhibitors [7].

The current study aimed at evaluating the sequential expression of peripheral blood ABCG2 gene expression following adjuvant chemotherapy in newly diagnosed breast cancer patients, in order to assess the effectiveness of ABCG2 substrate chemotherapeutic drugs and to highlight the need for alternative local protocols for the treatment of chemotherapyresistant breast cancer.

\section{PATIENTS AND METHODS}

\section{Patients}

Thirty newly diagnosed female metastasis-free breast cancer patients aged 25-60 years were selected 
from El Salaam Oncology Center (Specialized Medical Center, Ministry of Health, Cairo, Egypt). Diagnosis of all patients was based on standard clinical criteria including the tumor marker CA15.3, histopathology of biopsy samples from breast tissues, mammogram and computerized tomography (CT) scans.

\section{Study Design}

The study included sixty women; thirty newly diagnosed breast cancer (NDBC) patients and 30 healthy women volunteers (Control) matched for age. All subjects gave written informed consent to participate in the study. Breast cancer patients were routinely treated according to the National Cancer Treatment Guidelines of the Higher Committee of Cancer (Egyptian Ministry of Health and Population) following National Comprehensive Cancer Network (NCCN) Guidelines for the treatment of invasive breast cancer. Patients received a six-cycle adjuvant chemotherapy regimen (one cycle/three weeks) starting immediately after mastectomy. The intravenous FAC regimen consists of 5 -flurouracil $\left(500 \mathrm{mg} / \mathrm{m}^{2}\right)$, doxorubicin $\left(50 \mathrm{mg} / \mathrm{m}^{2}\right)$ and cyclophosphamide $(500$ $\mathrm{mg} / \mathrm{m}^{2}$ ). In case of heart diseases, patients received intravenous epirubicin $\left(100 \mathrm{mg} / \mathrm{m}^{2}\right)$ instead of doxorubicin. Both doxorubicin and 5-flurouracil are known substrates for ABCG2 [8].

\section{Tissue and Blood Sample Collections}

Cancer lumps and some normal breast tissue around the lump were removed from extirpated specimens at surgery and immediately placed in liquid nitrogen then stored at $-80^{\circ} \mathrm{C}$. Peripheral blood samples were collected with EDTA one day before surgical operation (First-NDBC), and after receiving three and six cycles of chemotherapy (Mid- and Last-NDBC, respectively). All blood samples were stored at $-80^{\circ} \mathrm{C}$.

\section{RNA Extraction and Real-Time Quantitative PCR}

Total cellular RNA was extracted from peripheral whole blood and frozen tissues using RNeasy ${ }^{\circledR}$ Mini kits (Qiagen, Hilden, Germany). The concentration and purity of total RNA were then assessed by measuring absorbance at 260 and $280 \mathrm{~nm}$, respectively, in a spectrophotometer (Nano Drop 2000, Thermo Scientific, USA). Reverse transcription of the extracted RNA to synthesize first strand complementary DNA (cDNA) was performed using AMV Reverse Transcriptase kit (Promega, WI, USA). Real-time PCR amplification and analysis were performed in $A B I$ PRISM 7500 Fast Sequence Detection System
Thermal Cycler (Applied Biosystems, California, USA), using Power SYBR ${ }^{\circledR}$ Green PCR Master Mix (Applied Biosystems, USA). PCR conditions were fifteen sec at $95^{\circ} \mathrm{C}$ (denaturation step), sixty sec at $60^{\circ} \mathrm{C}$ (annealing and extension) for forty cycles. Primers used for ABCG2 gene were 5'-CAATGGGATCATGAAACCTG3' (forward primer) and 5'-GAGGCTGATGAATGGA GAA-3' (reverse primer) and GAPDH (housekeeping gene) were 5'- ACCACAGTCCATGCCATCAC-3' (forward primer) and 5'- TCCACCACCCTGTTGCT GTA-3' (reverse primer). The expression of GAPDH was normalized between samples in each set, so that the relative expression of ABCG2 gene could be established. For each experimental sample, the amount of ABCG2 gene and endogenous reference (GAPDH) was determined. The relative expression of the RT-PCR amplified products and the fold change in the target gene were determined by the $\Delta \Delta \mathrm{Ct}$ method [9]. This method calculates the relative expression rate of the gene of interest by calculating the difference in expression, expressed as cycle threshold (Ct) cycle, between the test gene and the reference gene $(\Delta \mathrm{Ct})$ compared to that of the control samples (calibrator) $(\Delta \Delta \mathrm{Ct})$ then calculating the fold induction using the formula $2^{-(\Delta \Delta C t)}$.

\section{Statistical Methods}

The Shapiro-Wilks test for normality $(p>0.05)$ showed that all data were non-parametric. The quantitative results were expressed as median, $25^{\text {th }}$ and $75^{\text {th }}$ percentile (quartiles) values. The nonparametric Mann-Whitney $U$ test was used for comparing results between two independent groups. Wilcoxon test for multiple comparisons of nonparametric data was applied followed by Friedman's test to compare repeated measurements. Spearman's correlation was used to measure statistical dependence between two variables. Receiver operating characteristic (ROC) curves were constructed, and the area under the curve (AUC) was calculated to assess the diagnostic accuracy of ABCG2 gene expression. Crosstabulation analysis was carried out and the significance $x^{2}$ and likelihood ratio (LR) were calculated from the chosen cut-off values. The results were computed and all statistics were analyzed using SPSS statistical software version 20.0 (SPSS Inc., Chicago, IL, USA).

\section{RESULTS}

The baseline characteristics of NDBC patients included in the study were shown in Table 1. Data 
Table 1: Baseline Characteristics of Newly Diagnosed Breast Cancer (NDBC) Patients Included in the Study

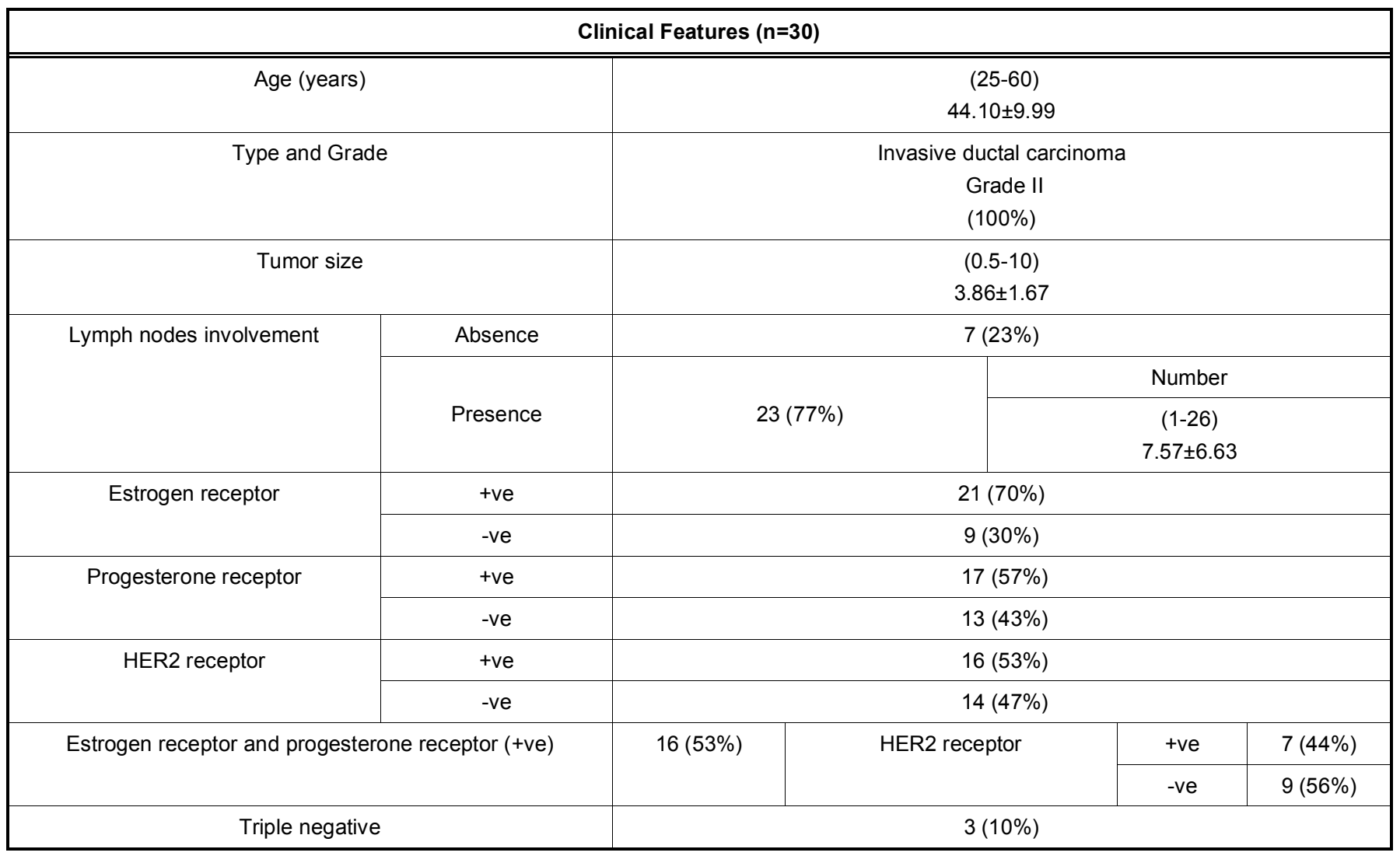

Results are mean \pm standard deviation.

Table 2: Change in Blood ABCG2 mRNA Gene Expression between Different Treatment Stages of Newly Diagnosed Breast Cancer (NDBC) Patients and Healthy Subjects, as well as among Different Treatment Periods

\begin{tabular}{|c|c|c|c|c|}
\hline & \multirow{2}{*}{$\begin{array}{l}\text { Control } \\
(n=30)\end{array}$} & First- NDBC & Mid-NDBC & Last-NDBC \\
\hline & & \multicolumn{3}{|c|}{$(n=30)$} \\
\hline Median & 1.00 & $2.04^{*}, \#$ & $3.45^{*, \dagger}$ & $5.60^{*}, \pm$ \\
\hline IQR & $(1.00-1.04)$ & $(1.70-2.53)$ & $(2.45-4.35)$ & $(4.25-6.80)$ \\
\hline$p<$ & \multicolumn{4}{|c|}{0.001} \\
\hline
\end{tabular}

"Significant versus control (Mann-Whitney $U$ test). Significant ${ }^{\#}$ versus Mid- and Last-NDBC, ${ }^{\dagger}$ versus First- and Last-NDBC, and ${ }^{\ddagger}$ versus First- and Mid-NDBC (Friedman test followed by Wilcoxon test for repeated measurements).

presented in Table 2 demonstrate a sequential significant increase in the expression of peripheral blood ABCG2 gene in NDBC starting at baseline and by the end of the third and sixth cycles of chemotherapy, compared to healthy subjects $(p<0.001$, Mann-Whitney $U$ test), and among different periods $(p<0.001$, Friedman test followed by Wilcoxon test for repeated measurements). In addition, the expression of ABCG2 gene in cancerous specimens of NDBC patients was significantly increased, compared to normal breast samples of the same patients $(p<0.001$, Student's $t$ test) (Table 3). Receiving operating curves (ROC) were generated for blood ABCG2 gene expression of NDBC patients at baseline (First-NDBC), as well as tissue ABCG2 gene expression, and the sensitivity, specificity, area under the curve (AUC) and the best cut-off values that discriminate between NDBC patients and healthy subjects were detected (Figure 1, Table 4). According to the calculated cut-off values, cross-tabulation demonstrates that blood and tissue, ABCG2 gene expression was able to significantly differentiate between NDBC patients and control subjects according to the likelihood ratio presented (Table 5). Progression of disease (recurrence or metastasis) in breast cancer patients was positively correlated with lymph node involvement and numbers, 
Table 3: Statistical Significance of Tissue ABCG2 mRNA Gene Expression of NDBC Patients in Cancer Lumps Versus Normal Breast Samples

\begin{tabular}{|c|c|c|}
\hline & $\begin{array}{c}\text { Normal } \\
(\mathbf{n = 3 0})\end{array}$ & $\begin{array}{c}\text { Cancer } \\
(\mathbf{n}=\mathbf{3 0})\end{array}$ \\
\hline \hline Mean $\pm S D$ & $1.01 \pm 0.04$ & $(4.02-10.3)$ \\
\hline Range & $(0.93-1.08)$ & $96 \%$ \\
\hline Change\% & -- & 0.001 \\
\hline$p<$ & & 00 \\
\hline
\end{tabular}

Student's t test for parametric data ( $\mathrm{p}<0.001)$.

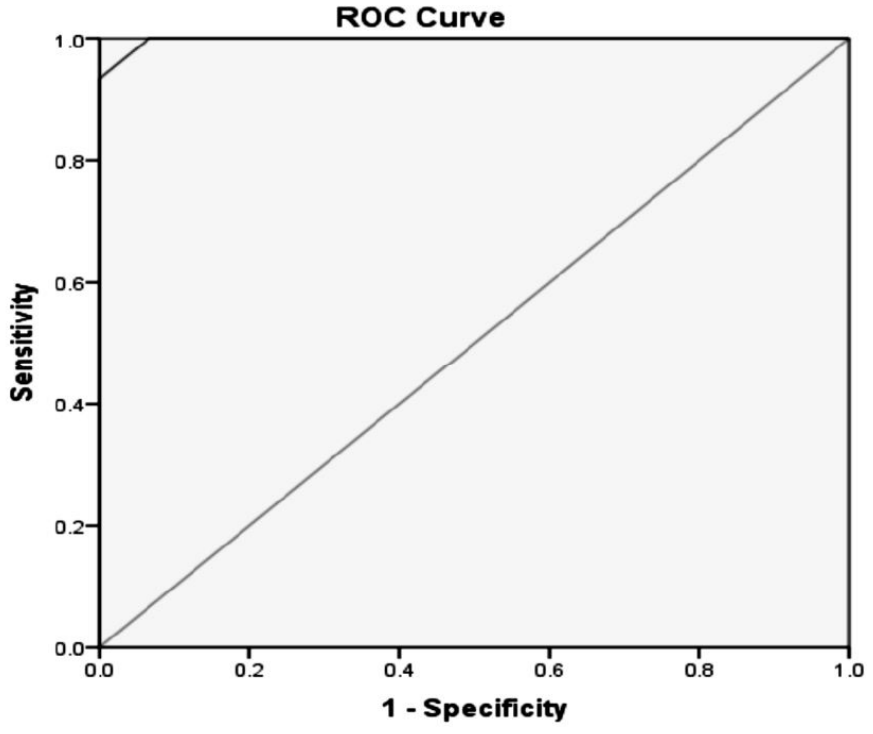

A

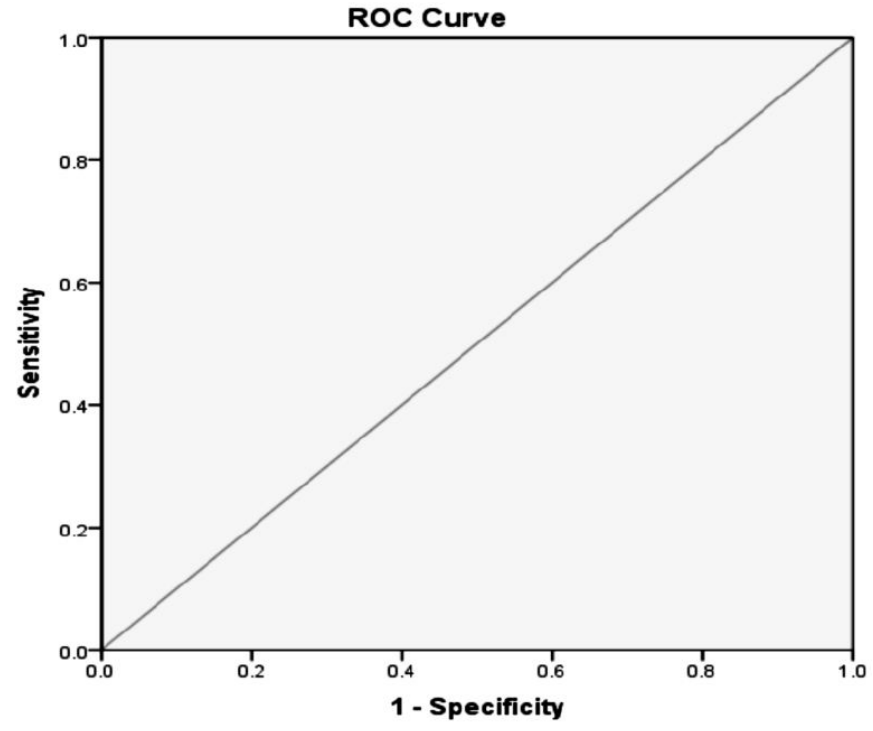

B

Figure 1: Receiver operating characteristic (ROC) curves showing the area under curve (AUC) for blood (A) and tumor (B) ABCG2 mRNA gene expression in NDBC patients versus healthy subjects.

Table 4: Sensitivity, Specificity and Cut-Off Values of Blood and Tissue ABCG2 mRNA Gene Expression

\begin{tabular}{|c|c|c|c|c|c|c|c|c|c|}
\hline & & \multirow[t]{2}{*}{ AUC } & \multirow[t]{2}{*}{ SE } & \multirow[t]{2}{*}{$p<$} & \multicolumn{2}{|c|}{$95 \% \mathrm{Cl}$} & \multirow{2}{*}{$\begin{array}{l}\text { Cut-off } \\
\text { value }\end{array}$} & \multirow{2}{*}{$\begin{array}{c}\text { Sensitivity } \\
\%\end{array}$} & \multirow{2}{*}{$\begin{array}{c}\text { Specificity } \\
\%\end{array}$} \\
\hline & & & & & LB & UB & & & \\
\hline \multirow{2}{*}{ 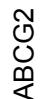 } & Blood & 0.998 & 0.003 & 0.001 & 0.99 & 1.00 & 1.25 & $93.3 \%$ & $100 \%$ \\
\hline & Tissue & 1.000 & 0.001 & 0.001 & 1.00 & 1.00 & 2.56 & $100 \%$ & $100 \%$ \\
\hline
\end{tabular}

expression of human epidermal growth factor 2 (HER2), as well as Mid- and Last-NDBC blood ABCG2 gene expression. By contrast, the disease progression was negatively correlated with estrogen and progesterone receptors expression. On the other hand, progesterone receptor expression was positively correlated with estrogen receptor expression and negatively correlated with triple negative cases (Table 6). Regarding the response of patients to adjuvant chemotherapy, 15 out of 30 patients (fifty percent) respond to the treatment and were disease-free, whereas the remaining patients were resistant, with local recurrence (5 patients with one death), bone metastasis ( 5 patients) and 5 patients were shifted to Taxol treatment. The selected significant parameters in NDBC patients show that patients with positive lymph node involvement and HER2 expression are more susceptible for disease progression (recurrence or metastasis), whereas patients with positive estrogen or progesterone hormone receptor expression are less susceptible for disease progression (Table 7). 
Table 5: Cross-Tabulations Showing the Reliability of Blood and Tumor ABCG2 mRNA Gene Expression between NDBC Patients and Healthy Subjects

\begin{tabular}{|c|c|c|c|c|c|c|c|}
\hline & rameter & Cut-off values & Counts & Control & Breast cancer & $x^{2}$ & LR \\
\hline \multirow{7}{*}{ 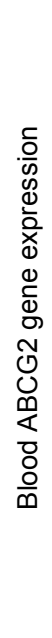 } & \multirow[t]{3}{*}{ First- NDBC } & $\leq 1.25$ & $\mathrm{n}$ & 30 & 2 & \multirow[t]{3}{*}{0.001} & \multirow[t]{3}{*}{68.22} \\
\hline & & \multirow[t]{2}{*}{$>1.25$} & $\mathrm{n}$ & 0 & 28 & & \\
\hline & & & $\%$ & $0 \%$ & $93.3 \%$ & & \\
\hline & \multirow{3}{*}{ Mid- NDBC } & $\leq 1.25$ & $\%$ & $100 \%$ & $0 \%$ & \multirow{3}{*}{0.001} & \multirow{3}{*}{83.18} \\
\hline & & \multirow[t]{2}{*}{$>1.25$} & $\mathrm{n}$ & 0 & 30 & & \\
\hline & & & $\%$ & $0 \%$ & $100 \%$ & & \\
\hline & Last- NDBC & $\leq 1.25$ & $\mathrm{n}$ & 30 & 0 & 0.001 & 83.18 \\
\hline \multirow{4}{*}{\multicolumn{2}{|c|}{$\begin{array}{c}\text { Tissue ABCG2 gene } \\
\text { expression }\end{array}$}} & \multirow[t]{2}{*}{$\leq 2.56$} & $\mathrm{n}$ & 30 & 0 & \multirow[t]{4}{*}{0.001} & \multirow[t]{4}{*}{83.18} \\
\hline & & & $\%$ & $100 \%$ & $0 \%$ & & \\
\hline & & \multirow[t]{2}{*}{$>2.56$} & $\mathrm{n}$ & 0 & 30 & & \\
\hline & & & $\%$ & $0 \%$ & $100 \%$ & & \\
\hline
\end{tabular}

$\mathrm{X}^{2}$ : Pearson chi-square; LR: Likelihood ratio.

Table 6: Significant Correlations between Chosen Markers in NDBC Patients

\begin{tabular}{|c|c|c|c|}
\hline & Parameters & $\mathbf{r}^{*}$ & $p<$ \\
\hline \multirow[t]{5}{*}{ Progression } & Lymph nodes involvement & 0.394 & 0.031 \\
\hline & Estrogen receptor expression & -0.36 & 0.048 \\
\hline & Progesterone receptor expression & -0.471 & 0.009 \\
\hline & Mid-NDBC ABCG2 gene expression & 0.540 & 0.002 \\
\hline & Last-NDBC ABCG2 gene expression & 0.652 & 0.001 \\
\hline \multirow[t]{2}{*}{ Progesterone receptor expression } & Estrogen receptor expression & 0.602 & 0.001 \\
\hline & Triple negative & -0.381 & 0.038 \\
\hline
\end{tabular}

Spearman's correlation; $r^{*}$ : Correlation coefficient.

\section{DISCUSSION}

Chemotherapy is a major form of treatment for various cancers. However, a major obstacle for the effective chemotherapy is multi-drug resistance (MDR), where cells resist numerous structurally and functionally unrelated drugs via increasing drug effluxing that reduces their concentration in the cells $[10,11]$. It has been reported that clinical resistance to chemotherapy in a series of cancers may come with poor prognosis and high risk of death [12].
A large number of hematological malignancies and solid tumors have been detected as exhibiting ABCG2 [13]. Also, ABCG2 is overexpressed in highly aggressive breast cancers [14] and is considered critically responsible for drug resistance in mammalian cells [15]. Increased ABCG2 transporter expression and activity have been implicated in unresponsive breast cancer patients, while its inhibition has been shown to restore cell sensitivity to chemotherapeutic drugs [16]. In the current study, assaying peripheral 
Table 7: Cross-Tabulations Showing the Reliability of Some Markers at Initial Diagnosis and the Progression of the Disease in NDBC Patients

\begin{tabular}{|c|c|c|c|c|c|c|}
\hline \multirow[b]{2}{*}{ Parameter } & & & \multicolumn{2}{|c|}{ Progression } & \multirow[b]{2}{*}{$x^{2}$} & \multirow[b]{2}{*}{ LR } \\
\hline & & & Free & Recurrence or metastasis & & \\
\hline \multirow{4}{*}{$\begin{array}{l}\text { Lymph node } \\
\text { involvement }\end{array}$} & \multirow[t]{2}{*}{ Negative } & (n) & 6 & 1 & \multirow[t]{4}{*}{0.031} & \multirow[t]{4}{*}{5.06} \\
\hline & & $\%$ & $85.7 \%$ & $14.3 \%$ & & \\
\hline & \multirow[t]{2}{*}{ Positive } & (n) & 9 & 14 & & \\
\hline & & $\%$ & $39.1 \%$ & $60.9 \%$ & & \\
\hline \multirow{4}{*}{$\begin{array}{l}\text { Estrogen receptor } \\
\text { expression }\end{array}$} & \multirow[t]{2}{*}{ Negative } & (n) & 2 & 7 & \multirow[t]{4}{*}{0.046} & \multirow[t]{4}{*}{4.14} \\
\hline & & $\%$ & $22.2 \%$ & $77.8 \%$ & & \\
\hline & \multirow[t]{2}{*}{ Positive } & (n) & 13 & 8 & & \\
\hline & & $\%$ & $61.9 \%$ & $38.1 \%$ & & \\
\hline \multirow{4}{*}{$\begin{array}{l}\text { Progesterone receptor } \\
\text { expression }\end{array}$} & \multirow[t]{2}{*}{ Negative } & (n) & 3 & 10 & \multirow[t]{4}{*}{0.01} & \multirow[t]{4}{*}{6.95} \\
\hline & & $\%$ & $23.1 \%$ & $76.9 \%$ & & \\
\hline & \multirow[t]{2}{*}{ Positive } & (n) & 12 & 5 & & \\
\hline & & $\%$ & $70.6 \%$ & $29.4 \%$ & & \\
\hline \multirow[t]{4}{*}{ HER2 expression } & \multirow[t]{2}{*}{ Negative } & (n) & 10 & 4 & \multirow[t]{4}{*}{0.028} & \multirow[t]{4}{*}{4.96} \\
\hline & & $\%$ & $71.4 \%$ & $28.6 \%$ & & \\
\hline & \multirow[t]{2}{*}{ Positive } & (n) & 5 & 11 & & \\
\hline & & $\%$ & $31.3 \%$ & $68.8 \%$ & & \\
\hline
\end{tabular}

$X^{2}$ : Pearson chi-square; LR: Likelihood ratio.

blood ABCG2 gene expression in NDBC patients receiving adjuvant chemotherapy was fulfilled in order to evaluate the effectiveness of treatment. Initially, the expression of ABCG2 gene in tumor tissues of NDBC patients was significantly increased, compared to normal breast samples. Furthermore, a sequential significant increase was recorded in the expression of peripheral blood ABCG2 gene expression in NDBC patients at baseline and by the end of both cycles of chemotherapy, compared to healthy subjects, and among different treatment periods. ABCG2 transporter is known to confer resistance to anthracycline anticancer drugs [17], and it is therefore clear that an MDR phenotype and a non-response effect occurred in Egyptian NDBC patients receiving adjuvant chemotherapy under the current treatment protocol.

The ABCG2 overexpression has been associated with cancer progression by promoting proliferation and antiapoptosis via MAPK signaling pathway in laryngeal squamous cell carcinoma [18]. We recorded a positive correlation between disease progression (recurrence or metastasis) in NDBC patients receiving chemotherapy and peripheral blood $A B C G 2$ gene expression. Thus far, our results reveal that $A B C G 2$ gene overexpression following chemotherapy treatment of NDBC patients may be correlated with a poor outcome. More interestingly, hormone sensitive NDBC patients (ER+ve or PR+ve) were found to be less susceptible for disease progression (recurrence or metastasis), whereas NDBC patients with positive lymph node involvement and HER2 expression are more susceptible for disease progression.

\section{CONCLUSION}

The adopted regimen herein that includes routine mastectomy followed by adjuvant chemotherapy must be reconsidered, as not all the diagnosed breast cancer patients in the current study respond to the chemotherapy by virtue of the sequential increase of ABCG2 mRNA gene expression. Therefore, ABCG2 gene expression does not only evaluate chemotherapy effectiveness in early diagnosed breast cancer patients, but also may be a biomarker predictor for clinical prognosis and disease progression.

\section{CONFLICT OF INTEREST}

The authors declared no potential conflicts of interest with respect to the research, authorship, and/or publication of this article. 


\section{FUNDING}

The authors received no financial support for the research, authorship, and/or publication of this article.

\section{REFERENCES}

[1] Siegel RL, Miller KD, Jemal A. Cancer Statistics, 2018. CA Cancer J Clin 2018; 68: 7-30. https://doi.org/10.3322/caac.21442

[2] Globocan. Global Health Observatory 2018. http://gco.iarc.fr/today/data/factsheets/populations/818-egyptfact-sheets.pdf

[3] Gottesman MM, Lavi O, Hall MD, et al. Toward a Better Understanding of the Complexity of Cancer Drug Resistance. Annu Rev Pharmacol Toxicol 2016; 56: 85-102. https://doi.org/10.1146/annurev-pharmtox-010715-103111

[4] Zahreddine H, Borden KL. Mechanisms and Insights into Drug Resistance in Cancer. Front Pharmacol 2013; 4: 28. https://doi.org/10.3389/fphar.2013.00028

[5] Khunweeraphong N, Szöllösi D, Stockner D. et al. The ABCG2 Multidrug Transporter is a Pump Gated by a Valve and an Extracellular Lid. Nat Commun 2019; 10(1): 5433. https://doi.org/10.1038/s41467-019-13302-2

[6] Bhardwaj B, Baidya ATK, Amin SA, et al. Insight into Structural Features of Phenyltetrazole Derivatives as ABCG2 Inhibitors for the Treatment of Multidrug Resistance in Cancer. SAR QSAR Environ Res 2019; 30: 457-475. https://doi.org/10.1080/1062936X.2019.1615545

[7] Toyoda $Y$, Takada T, Suzuki H. Inhibitors of Human ABCG2: From Technical Background to Recent Updates with Clinical Implications. Front Pharmacol 2019; 10: 208. https://doi.org/10.3389/fphar.2019.00208

[8] Yuan J, Lv H, Peng B, et al. Role of BCRP as a Biomarker for Predicting Resistance to 5-Fluorouracil in Breast Cancer. Cancer Chemother Pharmacol 2009; 63(6): 1103-10. https://doi.org/10.1007/s00280-008-0838-z

[9] Livak KJ, Schmittgen TD. Analysis of Relative Gene Expression Data Using Real-Time Quantitative PCR and the 2(-Delta Delta C (T)) Method. Methods 2001; 25: 402-408. https://doi.org/10.1006/meth.2001.1262
[10] Liu L, Zuo LF, Guo JW. ABCG2 Gene Amplification and Expression in Esophageal Cancer Cells with Acquired Adriamycin Resistance. Mol Med Rep 2014; 9: 1299-1304. https://doi.org/10.3892/mmr.2014.1949

[11] Kalimutho M, Parsons K, Mittal D, et al. Targeted therapies for triple-negative breast cancer: Combating a stubborn disease. Trends Pharmacol Sci 2015; 36: 822-846. https://doi.org/10.1016/j.tips.2015.08.009

[12] Bartholomae S, Gruhn B, Debatin KM, et al. Co-expression of Multiple ABC-Transporters is Strongly Associated with Treatment Response in Childhood Acute Myeloid Leukemia. Pediatr Blood Cancer 2016; 63: 242-247. https://doi.org/10.1002/pbc.25785

[13] Omran OM. The prognostic Value of Breast Cance Resistance Protein (BCRP/ABCG2) Expression in Breast Carcinomas. J Environ Pathol Toxicol Oncol 2012; 31: 367376. https://doi.org/10.1615/JEnvironPatholToxicolOncol.2013006 $\underline{767}$

[14] Collina F, Di Bonito M, Li Bergolis V, et al. Prognostic Value of Cancer Stem Cells Markers in Triple-Negative Breast Cancer. BioMed Res Int 2015. https://doi.org/10.1155/2015/158682

[15] Zhang W, Yu F, Wang Y, et al. Rab23 Promotes the Cisplatin Resistance of Ovarian Cancer via the Shh-Gli-ABCG2 Signaling Pathway. Oncol Lett 2018; 15: 5155-5160. https://doi.org/10.3892/ol.2018.7949

[16] Palasuberniam $P$, Yang $X$, Kraus $D$, et al. ABCG2 Transporter Inhibitor Restores the Sensitivity of Triple Negative Breast Cancer Cells to Aminolevulinic AcidMediated Photodynamic Therapy. Sci Rep 2015; 5. https://doi.org/10.1038/srep13298

[17] Gerk PM, Vore M. Regulation of Expression of the Multidrug Resistance-Associated Protein 2 (MRP2) and its Role in Drug Disposition. J Pharmacol Exp Ther 2002; 302: 407-415. https://doi.org/10.1124/jpet.102.035014

[18] Chen YL, Chen PM, Lin PY, et al. ABCG2 overexpression confers poor outcomes in hepatocellular carcinoma of elderly patients. Anticancer Res 2016; 36: 2983-2988.

DOI: http://dx.doi.org/10.30683/1929-2279.2019.08.04

(C) 2019 Soliman et al.; Licensee Neoplasia Research.

This is an open access article licensed under the terms of the Creative Commons Attribution Non-Commercial License (http://creativecommons.org/licenses/by-nc/3.0/) which permits unrestricted, non-commercial use, distribution and reproduction in any medium, provided the work is properly cited. 